\title{
Dissemination of Research Results
}

\section{and a National Information Policy}

Significant portions of the major primary and secondary publications in science and technology carry information resulting from government research and development. Sufficient allocation from federal research budgets is urged to cover costs of disseminating this new information in accordance with the long-standing thesis among scientists that transfer of information is an inseparable part of the research process. Relief would result to libraries whose subscriptions, in effect, now subsidize part of the information dissemination of government-supported research activity. Application of this principle would also assure a strengthened national bibliographic structure and broader user access.

$\mathbf{T}$ HE PERSPECTIVE of this paper was originally proposed to be that of a "specialized private university, which also places great emphasis on quality research and graduate education." These are not particularly unique characteristics among university libraries, so attention will be focused on concerns as they relate particularly to science and technology. Any contribution I may make will be due to the fact that these disciplines are probably among those accounting for the greatest drain on materials budgets, not only at the Massachusetts Institute of Technology, but in most academic libraries.

An adequate information policy will, of course, have more than one general objective. Needs for knowledge and information have different origins and may serve quite different values. If we are to have support on anything like an adequate scale, funding, both direct and indirect, will be justified by, and derived from, several kinds of sources. I should note at the outset that, far from there having been significant support

Irma $Y$. Johnson is science librarian, Massachusetts Institute of Technology, Cambridge. for libraries in institutions of higher learning, it appears from my perspective that our colleges and universities have been subsidizing the government in the information dissemination segment of its own research and development ( $R$ \& $D)$ programs.

We do not have a constituency sufficiently powerful to bring about the level of global support for libraries and information services proposed by the ALA president's special committee at the 1978 Midwinter Meeting. So as one element in evolution toward a realizable national information design, we should ask our government to recognize a responsibility with respect to the costs of transfer of the enormous body of new knowledge it is causing to be generated at public expense. If this were done, a long step will have been taken toward the ultimate overall design goal.

\section{DISSEMINATION OF FEDERALLY FUNDED RESEARCH INFORMATION}

I would like to focus on this single aspect of national policy, which increasingly affects adversely the ability of the academic library to provide balanced collections and services to its users. I suggest that the absence of a 
responsible information policy, combined with enormous government investment in the creation of new knowledge and information, is straining professional society publication programs and distorting, even contorting, academic library acquisitions budgets.

Serials and journals commonly absorb an increasingly large portion of our materials budgets; the bulk of these expenditures for serials and periodicals lies in the areas of science and technology, to the detriment of other collections. My thesis rests on the observation that a large number of the articles in these expensive journals and report series carry acknowledgment of federal support. Academic libraries constitute the backbone of these journals' subscription lists; to me, it therefore follows that the millions of dollars we pay for these journals, in spite of page charges, substantially support and provide for the dissemination of government-generated information, including related secondary services.

Some might say, it is the library's reason for being to disseminate whatever information is required and from whatever source. Others might argue that overhead paid on grants and contracts is the funding mechanism the government uses to take care of this obligation. The fallacy in the latter theory is that it not only neglects to provide for non-research-based institutions, which should also acquire some of this material, but it really neglects the root problem of need for a system of support driven by the new publicly generated knowledge itself.

It might be well at this point to recall the premises of the 1963 report of the President's Science Advisory Committee on "Science, Government and Information." That report made the following statements:

1. "Transfer of information is an inseparable part of research and development."

2. "Insofar as the Federal Government is the main sponsor of both basic and applied research, it has the responsibility for the financial viability of the communication network whether it is within or without Government."

3. "Publication even in non-government media will eventually be largely paid by Government."
4. “. . . we see no other alternative to direct Government subsidy of secondary media."1

It is now fifteen years later; we have drifted even further into a marketplace philosophy of information as commodity rather than process; and the problem has grown worse. Between 1970 and 1977, while our academic library materials budgets have become more and more skewed, it has been reported that federal funding for scientific and technical information actually decreased as a fraction of the total R \& D budget. ${ }^{2}$

As you know, the research cycle begins with investigation, followed by reporting and publication, abstracting and indexing, and on to readers where the whole process starts over again. Through their subscriptions to primary and secondary publications covering this federally supported research, it would seem that academic institutions have essentially been subsidizing to a significant degree that segment of the information cycle in which the new research results are made publicly known and available.

It is not only unfair and increasingly impossible for academic libraries to carry this load, it is also poor stewardship of public funds to make our institutional financial vicissitudes a decisive factor in determining whether the new knowledge, bought at such cost, reaches those who might use it.

The federal R \& D budget was estimated at $\$ 27$ billion this year. ${ }^{3}$ As I have stated elsewhere, "A proper return on the public's investment in research and development is almost certainly a function of a systematic (though it would be fractionally small) allocation of a portion of that investment in the successive stages of dissemination and access; that is, publication (through increased page and other charges), intellectual access through secondary services, including their electronic format, and physical access through the knowledge store in libraries and other information facilities." 4

Because of the sheer volume of knowledge being generated, reference librarians and their users would also benefit from greater allocation of support for evaluation, synthesis, and generally packing down the literature. When the National Bureau of Standards published the International Critical Tables in the 1920 s and ' 30 s, their con- 
tent included a far larger proportion of the data that had originally appeared in the prímary literature than obtains in reference compilations today. It is true that federally supported "information analysis centers," the Bureau of Standards, and various mission-oriented groups produce, analyze, compile, and store prodigious quantities of data. But this information is not as physically and economically accessible as it should be to potential users, and so the basic investment is again dissipated.

Just as a supermarket does not have to deal every morning with the bulk delivery of hundreds of pounds of flour and sugar and crackers and pickles and breakfast food, so too bulk information must have adequate sorting and weighing and packaging and labeling and generally packing down. I don't want to imply that this kind of activity is not taking place. It is just that the magnitude does not appear to be on the same scale as the volume of funded research.

As I noted before, our government is currently spending $\$ 27$ billion in the creation of new knowledge (paying for salaries, laboratory equipment, computer time, etc.). And just when the process reaches the pay-off stage, when the research product should be read by someone, thus possibly justifying the taxpayer's investment, the government appears to lose interest and decides to leave it to the marketplace.

And so, we do have an information policy, and it says that anyone who has the money and/or the time to dig may have access to all the information created by public funds, which, theoretically at least, was justified only if someone ultimately reads it and makes use of it.

\section{COSTS OF RESEARCH AND INFORMATION DISSEMINATION}

To illustrate the grossness of this policy and the scale of costs of the research relative to the cost of dissemination, one might cite further data on research funded by the federal government. We have been suggesting only that the latter bear its responsibility for the dissemination costs related to the information it causes to be created. But let us say it were to pay all the costs of publication of science and technology journals and secondary services, whether carrying gov- ernment-generated information or not. It is estimated that even that amount would come to only 8 percent of the R \& D budget for $1977 . .^{5}$ (Most industries would think they were getting off easy to be able to distribute their products for 8 percent of the manufacturing cost.)

To focus on a small portion of the federal sector, one may look at research funded by the Department of Energy. Its R \& D budget for fiscal 1978 was approximately $\$ 4$ billion. ${ }^{6}$ The results appear in journals and report series.

The subtlety with which university libraries are pressed into the role of disseminator of government research is reflected in the notice in every issue of Energy Research Abstracts: "The libraries listed below purchase and maintain microfiche collections of DOE and foreign reports that are abstracted in ERA. Most of these libraries have microfiche reader-printers or other photocopy facilities with which to reproduce enlarged copies from microfiche. Charges for reproduction services vary."

A subscription to these DOE research reports on microfiche costs those of us who subscribe approximately $\$ 3,000$ a year, a not inconsiderable sum to any academic library today. To provide a file of these reports to 1,000 libraries would require the allocation of only three-fourths of 1 percent of the annual DOE research budget. Were the DOE to accept full responsibility for this final results-dissemination segment of its R \& D process, each subscribing library could devote $\$ 3,000$ to humanistic and other hardpressed disciplines. And for a little more, a responsible policy would facilitate cheap distribution of individual reports to anyone who will read them. It follows, too, that this principle might well apply also to that portion of the full subscription cost of the journals we all subscribe to which carry research results from Department of Energy R \& D.

Academic libraries have not only been subsidizing the distribution of research results in primary publications by their subscriptions to journals and research report series for which government page charges have been insufficient. An even greater impact on libraries can be seen in the costs of the secondary services covering the fields in 
which government R \& D is focused; and it is by no means limited to science and engineering.

Some government agencies, such as the Department of Energy and the National Institutes of Health, have responsibly supported the indexing services needed for research areas with which they are concerned; the costs of Energy Research Abstracts $(\$ 281)$ and Index Medicus $(\$ 170)$ are modest in comparison to the prices of Chemical Abstracts $(\$ 3,700)$, Biological Abstracts $(\$ 2,800)$, Engineering Index $(\$ 900)$, and many other services. Here again, the subscription prices to such privately supported services could be lowered if the costs of including the literature that has originated from federal research were covered by allocations to the secondary services based on the respective original research project budgets.

There may have been a time long ago when the volume of scientific literature was substantially less and subsidy for the input alone would have been small but appreciated. Today, given the capital investment required for secondary services in their electronic mode, Weinberg's statement is even more imperative: "We see no alternative to direct government subsidy of secondary media."7

This principle was reconfirmed by the National Commission on Libraries and Information Science in its 1972-73 annual report, when it stated that bibliographic services serving a wide segment of knowledge and a wide group of users should be designated and subsidized as national information utilities. $^{8}$

In the absence of such support, bibliographical services have only two alternatives: (1) raise subscription rates to levels resulting increasingly in cancellations or (2) reduce quality or volume of coverage.

The technology is such that if the government would responsibly support the organizational and technological infrastructure needed for optimum dissemination of its own research results, we should be on our way toward a national system that could and would carry much else as well. This is, of course, not an invitation for the government to take over the preparation and publication of secondary services, only a suggestion that it should pay its proportionate share by appropriate allocation of costs from research budgets.

\section{A Stronger National INFORMATION SYSTEM}

Without a national system incorporating this principle, because of the power of information technology, we shall shortly see an escalation of the situation in which the information-rich get richer and the information-poor get poorer. In the academic context, this means that faculty and students with government contracts have an advantage over those who don't, even if they have the same intellectual capacity for contribution and even if they are working in the same research area in which there is social need.

For those who can afford it, the electronic format of secondary services is speeding the research process and, as academic reference librarians can attest, computer searching is pointing to heretofore underutilized material in the knowledge store.

Our history is not without precedents on what to do when you have a large, underutilized, relatively unknown resource that takes too long to get to and to make use of. You find a way to subsidize a carrier system to speed up the process, not just for an elite or for the most enterprising, but for all. The building of the railroads in the last century contributed enormously to the rapid development and use of an underutilized and relatively unknown area. We should ask for no less vision today to help forge the infrastructure for information carriers to open up the increasingly large knowledge store, our twentieth-century underutilized "West."

A more recent example of the same phenomenon has further implications as an analogy to the national information problem. Several years ago at a radius some distance from Boston and Cambridge, a circumferential highway was proposed and started. When building began, all that country space was little used; but as construction proceeded and the access became visible, the space began to be gobbled up by industrial parks, light factories, research firms, etc. Before construction was even completed, the widening process had to be started; Route 128 was lined with these industries, 
and the automobiles from their employee parking lots numbered many thousands every day.

I think the way that space was gobbled up and the way the use of a new academic library building almost immediately leapfrogs the newly enhanced space is suggestive. So too, if access to the knowledge being created by our public investment is efficiently assured, it will be used; and the effort and money invested in its creation will be justified.

There is almost an unlimited capacity for individuals and organizations and societies to absorb and make use of new information. But access is critical if new knowledge is to be translated into economic growth, which, for the decision makers, is a prime justification for much R \& D effort. This objective of economic growth may be one coattail on which our proposals for support of a national information system might ride.

\section{CONCLUSION}

To sum up:

1. Under the present social system, new knowledge is the driving force for the innovation that spurs economic growth. For this reason, the federal investment in research will probably continue to be high.

2. A national information policy must recognize the functions of different kinds of libraries (public, school, academic, etc.) and ensure their support in a more direct way than has heretofore obtained (e.g., for preservation and conservation, now mistakenly assumed to be provided adequately by academic/research libraries).

3. A national information policy must also support academic and research libraries indirectly through allocation of increased support for primary and secondary carriers and processors of publicly generated research information. Such support will achieve benefits for libraries through reduction of outlays for materials and electronic secondary services. Indirect support of this sort would be, not only just as real an aid as direct grants; but for some parts of the collections, it would be a more feasible, pragmatic, and cost-effective approach than putting all hope on direct grants to libraries (or, as some government decision makers and information spokespeople keep proposing, by direct grants to users). Enhanced support at stages in the information cycle earlier than the library or the user may well prove directly supportive at later stages and, for some purposes, more cost-effective for the taxpayer.

4. Technology increasingly will be the principal determining factor in information transfer of all kinds. This technology already affects bibliographic services that libraries can offer their users. In the future it will affect access to text as well.

5. Our vast publicly supported research and development program calls for knowledge-driven information systems that will seek out and inform potential users. The latter must be accurately profiled, but the economic status of the recipient or that of his or her institution must not determine eligibility for access. A national information policy should build on a recognition that we live in an information environment suffused with "answers looking for questions,"9 and that the technical means for their finding each other is not the present principal barrier.

6. In an age of high technology, the absence of a national information policy committed to reducing the barriers to the effective flow of information (economic, "needto-know" regulations, etc.) should be seen as just as great a threat to the institutions of our civilization as censorship. As academics, we may draw some encouragement from the formation of committees on research libraries by the Association of American Universities and by the Association of Graduate Schools. However, it is incumbent on librarians themselves as knowledge professionals to bring our point of view to bear on policies being formed, and we shall have to do it with some acumen if we are not to have Proposition 13 quoted at us or to be advised that we represent no constituency.

I am not an economist, but it seems to me that these lines of thought beg for serious discussion and inquiry. If much more time elapses, the marketplace-based decisions now being made will have solidified, to the long-lasting detriment of full-information access.

The real crux of these matters has been beautifully stated by a special librarian, Janice Ladendorf, and it applies equally 
whether we are speaking of individuals, or of an academic institution, or of an industry, or of whole societies: "In today's informa- tion-rich environment, those who exploit these information resources most effectively are the ones who will succeed." 10

\section{REFERENCES}

1. President's Science Advisory Committee, Panel on Science Information, Science, Government and Information (Washington, D.C.: Govt. Print. Off., 1963), p.14, 19, 37.

2. Robert S. Cutler and Derek de Solla Price, "A Policy Perspective on Scientific and Technical Information Activities of the Federal Agencies," preprint, contributed paper, AAAS Annual Meeting 1977, p.2.

3. U.S. Bureau of the Census, Statistical Abstract of the United States, 1977 (Washington, D.C.: Govt. Print. Off., 1977), p.613.

4. Irma Y. Johnson, "Information Dissemination: What Ever Happened to the Weinberg Report?" (letter) Science 200:6 (April 7, 1978).

5. National Science Foundation, Division of Science Information, Statistical Indicators of Scientific and Technical Communication, 1960-1980 (Washington, D.C.: Govt. Print. Off., n.d.), v.1, p.77 (table 13), p.67 (table 86).
6. Willis H. Shapley and Don I. Phillips, Research \& Development in the Federal Budget: FY 1978 (Washington, D.C.: American Assn. for the Advancement of Science, 1977), p.50.

7. President's Science Advisory Committee, Science, Government and Information, p.37.

8. National Commission on Libraries and Information Science, Annual Report, 19721973 , p.3.

9. Cited by: Melvin Kranzberg, "Formal versus Informal Communication among Researchers," in Current Research on Scientific and Technical Information Transfer . . . 1976, Seminars sponsored by National Science Foundation, Division of Science Information (New York: Jeffrey Norton Publishers, n.d.) microfiche 5, paper 13, p.5.

10. Janice Ladendorf, "The Special Librarian in the Modern World," Special Libraries 61:535 (Dec. 1970). 